\title{
Universiteit
}

Leiden

The Netherlands

\section{Facing dilemmas: former Fulbe slaves in modern Mali}

Bruijn, M.E. de; Pelckmans, L.

\section{Citation}

Bruijn, M. E. de, \& Pelckmans, L. (2005). Facing dilemmas: former Fulbe slaves in modern Mali. Canadian Journal Of African Studies, 39(1), 69-96. Retrieved from https://hdl.handle.net/1887/9517

\footnotetext{
Version: $\quad$ Not Applicable (or Unknown)

License: $\quad$ Leiden University Non-exclusive license

Downloaded from: $\underline{\text { https://hdl.handle.net/1887/9517 }}$
}

Note: To cite this publication please use the final published version (if applicable). 
Konan, V. Touaregs. 1992. "La libération des sédentaires." Libertitres 14 juillet: 10 .

Lecocq, Baz. 2002. "That Desert Is Our Country: Tuareg Rebellions and Competing Nationalisms in Contemporary Mali (1946-1996)." PhD thesis, Amsterdam University.

Litny, Ibrahim. 1992. "Systèmes éducatifs et société touarègue: les Kel Adagh du nord du Mali." Mémoire de diplôme, Ecole des Hautes Etudes en Sciences Sociales.

Mann, Gregory. 2000. "The Tirailleurs Elsewhere: Military Veterans in Colonial and Post-colonial Mali, 1918-1968." PhD thesis, Northwestern University.

Marilko, Kélétigui. 1993. "L'attitude de l'administration face au servage." In Nomades et commandants: Administration et sociétés nomades dans l'ancienne $A O F$, edited by E. Bernus et al. Paris: Karthala.

Marty, André. 1993. "La répartition des terres lacustres du Gourma malien." In Nomades et commandants: Administration et sociétés nomades dans l'ancienne AOF, edited by E. Bernus et al. Paris: Karthala.

Nicolaissen, Johannes and Ida Nicolaissen. 1997. The Pastoral Tuareg: Ecology, Culture and Society. 2 volumes. London: Thames and Hudson.

Tidjani Alou, Mahaman. 2000. "Démocratie, exclusion sociale et qu_te de la citoyenneté: cas de l'association Timidria au Niger." Journal des africanistes 70, nos.1-2: 172-95. Winter, M. 1984. "Slavery and the Pastoral Twareg of Mali. Cambridge
Anthropology 9: 4-30.

\author{
Mirjam de Bruijn and Lotte Pelckmans
}

\section{Résumé}

Cet article illustre d'une part, la manière dont les hiérarchies Fulbe traditionnelles au centre du Mali ont clairement défini les relations de dépendance sociale, d'autre part leur rôle important dans la politique locale. Les anciens esclaves, les Rimaybe, luttent pour trouver une nouvelle place dans la société, en essayant de réconcilier passé et présent. Les récits historiques de trois groupes différents de Riimaybe dans des colonies différentes sont ici relatés. Après quatre décennies d'indépendance, et à une période où la conscience des droits de la personne et la démocratisation se sont accrues, comment envisagent-ils leur situation? La majorité des Riimaybe doivent faire face à des dilemmes sociaux et matériels liés à l'accès aux agences de développement, à l'éducation et à la politique. Leurs remarques sur l'identité sociale reflètent la dynamique des négociations en cours à l'intérieur des relations hiérarchiques actuelles.

\section{Introduction}

In 1997, presidential and legislative elections were held in Mali, the second set of elections to be held after the decision had been made in 1990 that the country would follow the road to democratization. In Douentza, where slavery used to form one of the pillars of the economy, and where the "traditional" chiefdom of the Fulbe dates from the time of the nineteenth-century Islamic Empire of Seeku Aamadu, the electoral contest was between supporters of party $A$ and party B. The chief of Douentza supported party B, but three of his former slave families supported party A. During the run-up to the elections, the notables of the chief tried to convince these three families to join B, which they refused to do. The chief's arguments were "we are one family" and "you have to follow your past," but 
the slaves were not willing to change their position, perhaps in an attempt to show the chief that slavery was, indeed, something of the past and that they were independent. Finally, party A won the elections. The chief was furlous and warned his slaves that if they did not follow him and his ideas, they risked losing their fields, land that belonged to the chief and his family. Ultimately, however, the chief did not take back his slaves' land.

The affair did not end here. These former slave families were not afraid of the chief so that during the harvest, they did as they had always done, giving the chief part of what they had harvested. But he refused to accept their "gift" and the slaves took it back home, a sign that the former relationship no longer existed. The "traditional" chiefs of the whole region organized a meeting to discuss the case. The chiefs condemned the chief of Douentza, who was said to be in the wrong: there is no place for democracy in the old rules! The time of repression by the traditional chiefs should now be over.

A few months later, there were elections to choose a mayor for the community and the same divisions were again evident. The candidate supported by the chiefs was Hassan Cisse, from party B. Party A won the elections once again, ending up with five representatives on the community council; Party B won four seats; and parties C/D two seats each. The latter two supported Hassan so he became the new mayor of Douentza, which was a disappointment for the "modern" inhabitants of Douentza and a reinforcement of "traditional" power.

This case illustrates how the traditional hierarchies, in which dependency relations are firmly defined, still play an important role in local politics and how they are always present even though slavery was abolished at least one hundred years ago. Furthermore, the case shows the dilemmas facing people who are part of these hierarchies. The chiefs are trying to maintain their power as they did in the past, but, at the same time, they recognize that their position in a democratizing or modernizing society is becoming problematic. The former slaves, called Riimaybe, are struggling to find a new position in society, in this case through local politics. As mentioned in the case description, only three families did not support the chief; the others all did. It seems to be difficult to remove the old relations of dependency. Indeed, in daily life in
Central Mali, where Douentza is situated, the hierarchical relationship between the nobles and "their" slaves is very visible, even to an outsider. This hierarchical relationship is a clear link to the history of the area, where the Fulbe created chiefdoms in the nineteenth century.

Slavery is a very realissue. As recent publications have shown, a large number of people still live under conditions of traditional slavery. ${ }^{1}$ We have no figures on the number of people in Fulbe society living as slaves, but the scarce literature on (former) slaves of the Fulbe sketches a society in which inequality was an essential element of the economy. The system of slavery has been replaced by a gradual scale of independence that can be defined both in economic terms (Meillassoux 1986), resembling, to some extent, feudal relations, and in kinship relations (Kopytoff and Miers 1977). The literature deals mainly with the differences between slaves and their masters (for example, Hardung 1997, 1998; Riesman 1977, 1992; Stilwell 1999; Vereecke 1994) but does not give clear reasons for the continuation of the institution in a different form. Botte (2003) is one of the few authors who has tried to explain the phenomenon, suggesting that slavery might have persisted because of the plurality of law, that is, modern versus customary law. As long as people remain under customary law, in which slavery in a certain form is accepted, the end of slavery will remain a long way off. In this article, we try to explain the persistence of the inequality between (former) slaves and their masters by analyzing the way slaves perceive themselves and how they define their own position in society by reflecting on the past.

(Former) slaves are currently facing numerous dilemmas that inform their social identity. As we discovered during our research (de Bruijn and van Dijk 1994; Pelckmans 2003), one of the important problems former slaves face is that they are "people without history" (Wolf 1981), or people whose history has been silenced (Trouillot 1995). Martin Klein formulates it as follows:

Slaves are present in oral traditions of the larger community, but only in passing. They are mentioned as followers, companions, or victims. Traditions are concerned with the deeds of leaders, rulers and founding heroes. Oral traditions give us little evidence about slavery; slaves have few traditions on their own $(1989,211)$. 
This is also the case for the historical narratives of the Hayre (Angenent, Breedveld, de Bruijn et van Dijk 2002). As Trouillot $(1995,5)$ argues, it is of less importance what this history is; what is important is how it works. In West African societies, having a history is central to the construction of one's social identity. Without a deep genealogy or without a tarikh (a written history) one is considered a non-person (Jansen and Zobel 2002; Evers 2002). So, similarly to Lambek (1996) and Shaw (2002), we interpret the memory of history as a social and moral practice in which the historical narrative informs a person on the construction of his/her social identity - who one is in one's group - and the rights and norms of society. Since this narrative is formulated by the powerful in society, and since others have to submit to this version of history and, thus, to their rules and norms, those in power succeed in creating non-persons. The extent to which former slaves succeed, today, in negotiating their past defines their freedom to construct their own social identity, as well as to direct their own
lives.

In the ethnographic material of this article, we hope to give former slaves a voice through a presentation of both their historical narratives and their current situations. What possibilities do former slaves have, today, to appropriate their own history and, consequently, power? How do they negotiate their past in the present? To unravel this narrative, we discuss the perspectives on history of (former) slaves, presenting data from different periods of fieldwork from 1987 to 2002 in Central Mali, a region known locally as the Hayre. ${ }^{2}$ We focus on three cases: the first is about Dalla, a village where the nineteenth-century kings resided the second describes Serma, a small hamlet situated in the middle of cattle camps; and the third is about the inhabitants of Douentza, a small town in the area.

\section{History of Slavery in the Hayre, Central Mali}

"Hayre" means rock or mountain in Fulfulde, the language of the Fulbe, and the name characterizes the area where the Fulbe kingdoms were situated. It is a mountainous area, a chain of rocky plateaus where they found protection and could fight off raiders coming from outside (Tuaregs). These mountains served as areas of refuge to which people fled in order to escape the atrocities of

surrounding empires and raiding groups. The area has a typical Sahelian climate, with long dry periods and huge fluctuations in rainfall. It is divided into two ecological zones: the plains and the foothills, where water is relatively scarce; and the mountains, which have access to water for most of the year. This ecological situation makes agricuilture in the area a risky affair, which might explain the kingdom's economies that were based on raiding and a slave economy (de Bruijn and van Dijk 1995).

The version of history as told by the bards of the Fulbe kings indicates the following sequence of events. ${ }^{3}$ In the seventeenth century, the Fulbe first came to the area from the Inner Delta of the Niger as raiding bands. They gradually developed more centralized power, which was institutionalized in the nineteenth century under the influence of the Fulbe Maasina Empire in the Inner Belta of the Niger. Fulbe kingdoms were established in the area during the second decade of the nineteenth century. This led to a strong islamization and hierarchization of society, in which a slave economy became the basis of society. Whole villages submitted to slavery (Griep 2004). A division was established between nobles and non-nobles, and there was a clear code of conduct concerning norms and values. From then onwards, it seems appropriate to talk of a slave economy (Finley 1981, 103). As Meillassoux (1982, 94) states: "Slavery was in no way a superficial feature of the organization of these societies; history cannot be understood if one ignores it!"

When the French conquered the area at the beginning of the twentieth century, they were confronted with a well-established slave economy, with slave markets in the region at Bandiagara and Hombori. French commandants who were based in Bandiagara reported the problems they had with the many raiding groups in the area, sketching a situation of turmoil, unrest, and repression. Indeed, this situation also emerges in the stories of old Riimaybe who still remember their fathers' and mothers' stories about being captured as slaves during these raids. An elderly former slave from Dalla who was visibly emotional, Allay Jangino, told us how his grandparents, "were sold at the market with ropes around their necks, like animals!" Stories reveal that slaves were often captured in adjacent areas or that they were in villages that were subjugated as slave estates. Some former slave families in the Hayre today can still trace their family's origins, and most former slaves know that 
their "real" second name is an expression of their original ethnic group.

Slaves, or the non-free, are the opposite of nobles - chiefs and their families, the Islamic clergy, and the herders - who, as nobles, were not allowed to do any hard work. The slaves did all the work and were not considered as part of the nobility (ndimu). Intermediate groups were the griots (artists) and the Diawaambe (merchants and traders), and these non-slave groups were all able to own slaves. The Diawaambe were the slave traders. The slaves themselves had become hierarchical, and the slaves of noble chiefs could also possess slaves. Related to this social opposition between slaves and the nobility was, and is, a complex set of rules and norms for behaviour (ndimu). Fulbe who belong to the pulaaku (the Fulbe community) are expected to behave according to these rules, nobles more so than the others. These rules are related to the behaviour of men and women in public, to maintaining a distance in certain social relations (mother and father-in-law, the old, and the young), to showing reserve and shyness in many situations, to not being greedy or noisy, and to being a good Muslim. ${ }^{4}$ Slaves did not live according to these rules and were even forced to behave in the opposite way, so as to highlight the social differences (Hardung 1997, 1998; Griep 2004; Riesman 1977, 1992).

\section{BeIng a SLAve}

Being captured as a slave meant that a person lost all his/her social relations and became a non-person. The old family name was no longer used, and the morals and customs of one's own people had to be forgotten. The slave received the name of his new master and had to obey him or her totally. The only role model these slaves had were those of their master and his group. For slaves living on socalled slave estates (that is, in slave villages), however, the situation was different. They also received the names of their masters but still lived together in a slave community. Today, these slave estates exist as villages, and they recognize their independence, which lingers in the stories they tell each other and in their interpretation of history. The master regulated marriage and heritage, and he decided about the names of slave children at birth. The master of the mother inherited children born out of slave unions. In fact, slaves were denied their own descent system and could not create lineages (Meillassoux 1986).

The division of work was also clear: slaves did all the work but received no benefits. Even families living on slave estates were forced to give a large part of their harvest to their masters. Slaves had no possessions. Land, for instance, was not theirs but belonged to the noble Fulbe, and any possessions were their masters', even their own children.

Paradoxically, a family relationship developed at the same time between masters and their slaves, and even more so between the noble chief families, along with the important Islamic clergy, and their slaves. The chiefs of the twentieth century married their slaves as fourth or fifth wives. Their children were free, and family alliances developed between these two groups. For the chiefs, these marriages were important to obtain the (political) support of their slaves. Other relations were created through those relations of confidence the chiefs had built up with their slaves (Kopytoff and Miers 1977). In Fulbe society, nobles do not trust each other, and the "higher" slaves were often advisors and persons of trust in these relationships (Stilwell 1999). Some people probably became slaves voluntarily, as in the case of the very poor, who preferred to become slaves in order to have some economic support and to ensure they were protected from other chiefs (Iliffe 1987).

The slaves (or non-free people or non-nobles) were essential for the economy of the Fulbe chiefdoms, doing all the work, producing all the food, and taking care of materials such as "banco" bricks for the construction of houses, mats for sleeping and sitting on, and musical instruments. Some groups even specialized in the weaving of cotton into cloths. In times of drought, it was the slaves who carried the burden of such a disaster. For example, during the drought of 1914, they were sent away by their own masters to look for food elsewhere. Probably, a lot of them never came back and thus paved the way for the abolition of slavery: the nobles left behind no longer disposed of their work force, and too few slaves were left to compensate for this exodus. Meanwhile, in wars and raids, slaves were the soldiers loyal to their masters, to whom they were often related, or whose trust person they became. This personal relationship could not develop between masters and slaves on the slave estates because they were not close enough physically. 
BECOMING FREE MEN

One of the most important changes the French introduced in the eyes of the Fulbe was the abolition of slavery. Anti-slavery measures became part of the motivation and legitimization of the civilizing mission of the colonial regime. The first official treaty stems from 1889 (the Treaty of Brussels), but the first practical steps in the fight against slavery were taken only from 1905 onwards (Klein 1998; Klein and Miers 1999; Kopytoff and Miers 1977). It was difficult to abolish slavery because from thirty to fifty percent of the economy was based on it, let alone the cultural aspects of this system. In the Hayre, the chiefs successfully resisted the French anti-slavery politics (de Bruijn and van Dijk 1995, Angenent, Breedveld, de Bruijn et van Dijk 2002). The trade in slaves and the raids were stopped, but the system as such was not touched in the first decades of colonial times. It was only after World War II that slavery was gradually abolished. But what did this mean for former slaves, who had no history of their own other than that of their relations with their masters? How did they, after four decades of independence, on the eve of a period of democratization, and in the age of human rights, see their own situation?

Before answering this question, we want to indicate that the definition of a "slave" is problematic since it is too static and cannot cover all the variations of the institution. Meillassoux (1986) tried to account for these variations by opposing the slave condition, that is, the personal career of a slave, to his slave estate (état), that is, the general condition of being enslaved. ${ }^{5}$ To further specify the notion of slave, we will refer to the local Fulfulde terms, namely Maccube (singular: Maccudo) and Riimaybe (singular: Diimaajo). The literal meaning of the term "Maccube" is explained differently in the literature, but most sources agree that it means "slave," those captured and their offspring. Riimaybe means protégé (Breedveld 1995) and not, as is often assumed, the opposite of rimbe, who are the noble people. As such, Riimaybe and Maccube may refer to different social categories who lived together. Under colonial rule, the term Riimaybe came to mean former slave. Although Maccube is the name for slaves in the past, some nobles call the present Riimaybe their Maccube in order to indicate that they are still enslaved. The former slaves themselves mostly use the name Riimaybe to stress the fact that they are free and that their status has changed.

In the past, all slaves in Fulbe society used to be called Maccube, but today former slaves are named differently in different Fulbe societies, for example RimDinaBe in Niger (Vereecke 1994), RunndeBe in Guinée (Botte 1994), JiyeeBe in Senegal (N'Gaide 1999), and GanunnkeeBe in Benin (Hardung 1997).

\section{Former Slaves: A Variety of Social Identities}

After the abolition of slavery, some Riimaybe groups migrated and never came back, leaving their masters for good. Others fled somewhere in the region, ending up in town or creating their own communities in hamlets such as Serma. A considerable number of Riimaybe opted to stay under the protection of their masters and, in fact, never freed themselves. These different strategies led to a variety of settlement patterns linked to the Riimaybe's reaction to the opportunity to become a free person. In the following section, we discuss these groups and their claims on history to explain the present. We thereby take into consideration intragroup differences based on age, gender, and personal history.

Dalla: Betwixt and between Modernity and Tradition

Dalla is a village at the foot of the mountains, where people were protected against raiding groups, and from where they could attack others. It was the stronghold of Fulbe chiefs in the nineteenth century and today is a chief village. It has three separate wards: one for the Diawaambe, one for the Moodibaabe (the Islamic lineage), and one for the noble warriors or chiefs, called Weheebe.

The spatial organization of Dalla suggests a dual relationship between the former slaves (the Riimaybe) and their former masters ${ }^{6}$ a relationship that is, on the one hand, characterized by being bonded and, on the other, by being separate. Each group in Fulbe society owned its own slaves: they had their own "slave reservoir," separated spatially from their own group in a "slave quarter." This can still be seen today: every residential quarter for nobles has its own Riimaybe area next to it. After independence, the chief's family built a wall to express their willingness to give "freedom" to their slaves. This willingness though only proved to be symbolic, as we will see.

Slaves were the "material" property of a noble family, doing all 
the manual work. They were not expected to behave according to Pulaaku rules and norms, and they were denied their own history. The historical narrative of the Riimaybe in Dalla is a copy of the masters' narrative, in which the masters' nobility and bravery are honoured. Stories about their own suffering are untold. Instead of complaining or rejecting their former adherence to the nobles, the Riimaybe of the Weheebe in Dalla took pride in their masters' history, thereby confirming their allegiance.

Local Politrcs: Balancing between Tradition and Modern GOVERnANCE

Local politics in Dalla are complex because of a dual system of governance. On the one hand, there is a chef de village (the village chief, who can be seen as the traditional village head, a social structure developed under the French regime), and, on the other, there is the mayor (the modern, democratically elected village head). With decentralization, the mayor should normally have replaced the traditional chef de village, but in Dalla, things worked out differently.

Mayor Muusa Dicko is always proud to present himself as the son of his father Yerowal Nuhun, the Chief of Dalla during colonial times, who reigned from 1916 to 1966 as a king. Yerowal was the last Fulbe "king" with slaves working for him. Yerowal's fourth wife was a slave from a slave estate near Dalla. She is the oldest living woman in Dalla today and had four sons, the oldest of whom is Muusa Dicko. Haidu the village chief, by contrast, was born out of Yerowal's marriage to a noble Pullo women. When Muusa was officially chosen as a mayor in democratic elections, he did not send his noble brother Haidu away. On the contrary, it seems that his role complements Muusa's well. Muusa Dicko aspired to a modern leadership role and was glad that his brother fulfilled the traditional tasks in the village.

Muusa's personality has many paradoxes. His way of governing can best be described as a continuation of the hierarchic tradition in a modern coat. On the one hand, he is the democratically chosen mayor who won votes because of his modern education and because the Riimaybe voted for him. They did so because he expressed a sense of familiarity with them and shared with them the fact that he, too, had Rimaybe blood running through his veins. Muusa's dual personality worked to his advantage, proclaiming both his slave and noble origins. Although sometimes acting as a democratic, noble, and modern mayor, who no longer adheres to tradition, he can also behave as a despotic king, referring to the Riimaybe as "his Maccube." In an interview (Douentza, January 2002), Muusa even expressed himself in the conservative discourse of the nobility about relations between nobles and their former slaves:

Riimaybe aren't free, we (nobles) won't free them, but even Riimaybe themselves don't want to be free. When they are freed, they will no longer have land to work on and what else can they do then? Nothing!

He then described his relation with them as follows: "Il y a toujours la corde" ("the rope will always exist").

\section{A Generational Recollection of History}

Allay is an old Diimaajo of about seventy-five years of age, who occupies a complex position in the Riimaybe quarter of the nobles. In Yerowal's (Muusa Dicko's father's) time, Allay worked as a child slave for Yerowal, who liked him and entrusted him with more and more responsibility, such as guarding the keys to the granaries and even to the prison. As a slave, Allay became one of Yerowal's most trustworthy councillors and gained prestige. Nowadays, he even occupies the position of head of the Riimaybe quarter of the mayor's family (Weheebe). When there are ritual festivities, it is Allay who decides which Diimaajo will slaughter the goats and sheep for which noblemen. Since slaughtering and preparing meat is considered impure, this is typically something performed by the Maccube or Riimaybe.

Although Allay is older than the current chief and mayor, and has always occupied a special position, he admitted that some years ago (when slavery had officially been abolished for a few decades), he decided to purchase his freedom. Until he was free, he could not aspire to all the Islamic activities such as slaughtering his own animals for Tabaski, and, in addition, he had to serve two masters, namely Allah and the mayor / chief. Therefore, he could not become a pious Muslim. He discussed this with some other Riimaybe friends, and, finally, they sought the advice of a Koranic teacher. He advised them not to mention their plans to their respec- 
tive masters and added that the money could better be spent on their masters' pilgrimage to Mecca. The masters would then have more prestige, and the prestige of the master would always reflect well on his slaves. Allay never mentioned the question again and lived his life as before, serving his two masters, while accepting his subordination in the practice of Islam.

Kodo's attitude is different; he is a good example of the younger generation's attitude. He is a young Diimaajo of about twenty-five years of age, who, after a broken marriage, went adventuring. In French, our interpreter said "partir en aventure," which means to go and look for a job outside one's own region, mostly in big cities, but also in other countries. We met him when he had just resettled in the village and was trying to pave the way for a peaceful future with his new wife. He was having some doubts about his religion, opting to convert from Islam to Christianity, in this way creating his own religious niche separate from the powerful group in his hometown. Furthermore, he was considering what options he had concerning the kind of economic activities that he could ideally develop. As a musician, he had made himself new drums and during the months after Tabaski, he played with his band on several ritual occasions such as marriages and circumcision rituals. Making music seems to be reserved for Riimaybe, who, next to griots, play musical instruments. In doing so, they inevitably confirm their lower status (being less Islamic), but at the same time, it allows them to earn money. Kodo made a good income from his drumming activity. His interpretation of Riimaybe-Weheebe relations is no longer formulated in a discourse of subordination because he opted for denying relics from the past. When we confronted him with the fact that Riimaybe actually work for their former masters during rituals and the rainy season (to help with harvesting), he replied that, today, they are paid for their work and he, therefore, considers it as a normal working relationship. He said that he had never known it any other way and that he had always been paid for work he had done.

Kodo's attitude contrasts with the sixty-five-year-old Kumba's, and with the fifty-year-old Seydou's. These members of the older generation have vivid memories of slavery, and they claimed that they would never ask their former masters to pay them for work they were "asked" to do. They would never refuse to do it, nor ask for compensation. They explained that they had too much respect for their (former) masters, and, therefore, they felt they should fear them. But even if they had not, their former master would make them.

Personal history and embodied experiences are the determining factors in one's social identity. The younger generation have only heard stories about the atrocities and anxieties of their parents' generation, but they do not have personal memories or experiences of it. They do not have difficulties in stating their independence. But what these young people proclaim in words is difficult to recognize in present-day life: the Riimaybe still do not have property rights over land, or noble women, democratic justice, education or, freedom of religion. Even though young Riimaybe such as Kodo have developed their own discourse on slave history and social identity, in which they deny all present subordination, they are not free in the same way as noble youngsters are.

Young Riimaybe present their "otherness" as the core of their identity - the fact that they are good at making money and are hard workers, who do not need to go to school and who do not even want to have access to noble women. Physical power and labour are at the core of their identity. This is what Ann McDougall (1988, 379 | calls their "work ethic." Hardung $(1997,129-31)$ explains this work ethic ideology as the way in which the Riimaybe (in Benin) oppose the psychological, political, and religious power of the nobles. However, in Mali, they do not appear to really challenge the nobles' psychological power. Some young people are succeeding in negotiating a new identity as freemen, for example, when they leave to go "on adventure." In a foreign place far from home, they can be a different person, but, then, they are without their families and usually even leave their families behind with the heavy burden of compensating for their absence to their master. This is why, for most Riimaybe, life abroad offers no definitive liberation of real status change. This is elaborated on in the following case of Maman Abidjan.

Dilemmas When Resisting Slave Status

"Dalla stinks, it is a terrible and dirty village!" was the comment of Diimaajo Maman Abidjan, an old women of about eighty years of age, who left Dalla because she was raped and had a child before 
she was married. She fled to the south, first to Bandiagara, before arriving in Abidjan, the capital of Côte d'Ivoire. Here, she married a ruch man, who married her for her beauty. Maman is lyrical about the years she spent in Abidjan. She told us she worked in a restaurant at the airport and had a nice stone house with a fan on the ceiling. Her husband had Senegalese-European parents, which gave him status (according to her). He died quite young; then, Maman discovered she was suffering from chronic diabetes, but she had a lot of friends who took care of her for years and even paid for her medicines.

But Maman's daughter and family in Dalla could not bear the idea of their (grand-/mother dying "alone" in Abidjan, which is why they brought her by plane and car all the way from Abidjan to Bamako, and then to Dalla, where she became very sick. Maman said that she never wanted to return to Dalla, where she was only a simple Diimaajo with no memorable past, who had to obey the rules of the nobles. In Abidjan, by contrast, she used to be a queen: she was considered beautiful and had a noble husband, who treated her well. He even arranged for her to go on a pilgrimage to Mecca, ensuring her a pious Muslim identity.

In Abidjan, Maman was only once confronted with her lowly origins and shameful past. Once, when she was at a wedding, one of the female hosts declared that she would not get her share of the women's money and that she had to do all the work because she was "but a slave." Luckily, a friend defended Maman, and Maman had the courage to sing as a praise singer, ${ }^{7}$ which categorized her as a griot, instead of as a slave. ${ }^{8}$ Maman's situation is intriguing: her personal glorious past does not seem to have given her the ability to deal with her other past as it was remembered and lived in Dalla. Using Meillassoux's (1986) terminology, her personal slave condition could not surpass her slave estate. When asked about her social position in Fulbe society, she was visibly uneasy:

Back in Abidjan I always considered myself as a Pullo, a free and pious women. ${ }^{9}$ Now I am back here in Dalla I am wondering: at ritual festivities I still have to take the place of a Diimaajo, a servant, and I still have to stick to traditional tasks even if I don't want to take this role. It is confusing and that is what I don't like about Dalla. I once brought sewing machines, cows and a lot of money to my family and the rest of the village. They "ate" it all and now I don't even get respect: even the children make fun out of me.

And the children do, indeed, make fun of her. Maman is a good victim because she cannot walk and has strange possessions (such as pictures, souvenirs from Mecca, and airplane boarding passes). Maman has become a person caught between two worlds: Dalla and Abidjan. In Dalla, a hegemonic historical discourse on slavery lingers that she detests but could not escape because it represents her origins. The other is the world in Abidjan, which she could appropriate only locally and temporarily while being there. In the end, Maman's family relations seem to determine who she is and though she has an alternative history, she cannot claim its validity by no longer being a slave.

The case of Dalla shows how difficult it is for people to free themselves of their masters, especially when, physically, they are so close to them, as the Riimaybe are in Dalla. In ritual and in politics, the very ambiguity of their "new" and "free" status comes to the fore: they are no longer real slaves, but then what, or who, are they? Non-slaves? Former slaves? In this kind of formulation, the dilemma clearly comes to the fore: they are no longer what they used to be, but who, then, are they, what is their alternative? What kinds of possibilities do they have to formulate a new identity, in which their past subordination cannot affect them any longer? Because of ever varying differences between the general slave estate and the personal conditions of slaves, as well as because of an unclear demarcation between past and present practices /since the process of abolition was so gradual and patchy), there was never a clear definition of the status (the duties and rights) Riimaybe now have or could, at least legally, claim.

\section{Riimaybe in a Hamlet: A Place of Escape?}

During the course of the twentieth century, some slave families took their new position as freed persons seriously, leaving their masters' villages. They opened up and cleared their own land, forming new hamlets across the plains of the Hayre. The Riimaybe hamlet of Serma, one hundred kilometres from Dalla, is an example of this type of settlement. ${ }^{10}$ Serma is a conglomeration of rainyseason cattle camps and a Riimaybe hamlet, which also serves as a market place. 
The history of Serma is special because it was there that a famous warrior and king of the Fulbe, Maamudu Nduuld, started to cultivate fields. It is, therefore, a historical place that is directly linked to the grand history of this area. The nobles in this region are all related in one way or another to Maamudu Nduuldi. The first story about Maamudu was recounted to us by one of the inhabitants in the Riimaybe hamlet, Bilaali, a sixty-year-old Diimaajo. He explained what a hero Maamudu was and how he had conquered the area and beaten his rivals, as well as how he had fought the Tuareg, before finally dying in a battle. He told this as a proud follower of the descendants of Maamudu, fully subscribing to the heroic history of the area. Its history, we later learned, was mainly the glory of the nobles, the noble political leaders in the area. Maamudu's army must have been full of soldiers who were forced to raid and capture slaves.

The Riimaybe hamlet of Serma consists of diverse families. It is not a real village, but rather a collection of houses, with no streets and sometimes not even paths from one house to the next. The majority of the families call themselves Riimaybe, but some pastoral Fulbe families also live there. They no longer have cattle or have only a few animals and have, thus, become marginalized, ending up in this modern version of a slave estate. There is a wide variety of houses: some are made from banco or millet stalks; they are either round or square; they have several rooms or sometimes just one; and they may be either well-kept or hopelessly dilapidated and neglected. The housing indicates differences in wealth and ethnic background, as well as the ad hoc character of this hamlet.

A few families are connected to the family of Maamudu Nduuldi and are the former slaves of his chief lineage. They call themselves Riimaybe but could not explain whether they were really free. They did not give money to the chief, and the chief did not declare them free either. What they did was move out of the vicinity of the chief and live in this hamlet where land had not been previously occupied. Here they could open up their own fields that could not be claimed by the Chief of Booni (the former Fulbe chiefdom in this area). Their relationship with the chief is comfortable, but they always obey his heroic family whenever they are called upon in their slave duties. Being linked to this family is profitable because they have access to development agencies, and they are always at the forefront of projects that come into the area. It would not be to these Rimaybe's advantage to deny an established relationship with this chief's family.

A few old women in this hamlet live alone and told us their stories of being former slaves of the herding Fulbe. When they were slaves, they used to go with them to herd their animals. From their way of presenting the past, it was clear that they regretted the fact that they were no longer allowed to do this work. Many herders lost a large number of their cattle during the droughts, and they can barely maintain their families economically, let alone their slaves. Keeping cattle is defined today as being ndimu, and as such noble Fulbe can do the herding themselves. This gives them an excuse to deny work to their slaves, whom they can no longer support. Nevertheless, the Riimaybe (who have never been officially freed) still appeal to their former masters, for example when there is a marriage for which they need money. Refusing to give them something would mean a break with ndimu, which noble Fulbe would never do.

The wish to return to former times of dependency and hard work can be explained by the present-day situation of these Riimaybe. Most of their children have died, and they find little support in the hamlet of Serma, which may be because they have no direct family linkages in the village and have to rely on their relationship with their former masters. Claims on their masters have become "illegal" since they do not work for them anymore.

Bilaali, the person who told us about the glorious past of Maamudu Nduuldi, is considered the leader of the hamlet, and he and his wife deny their slave backgrounds. According to them, they have always been Rimaybe and have never been linked to any have al such. He disclaims the linkage to his master who is Diawaando (a tradesman) in Dalla. This relationship was formed a generation ago, through the "gift" of a girl from Bilaali's family. Bilaali's father decided to live on his own and took his family to Bilaali's father decided to live on his own ane cleared fields there and became relatively successful cultivators. They had some cattle, and today a few animals have survived and are herded by various family members who now live near Bilaali. It was Bilaali's father who offered a free place to a Tuareg slave family, so-called Bella, who had fled their master and were seeking refuge. A few other Bella families joined the hamlet in 
the same way. Today, they also marry Riimaybe.

The hamlet has always offered refuge to people, and poor herdsmen can live there. Even a noble Tuareg couple who had no animals left and could not stay with their family found safety in Serma. They lived a life of dependence on the people of the hamlet, who would never refuse them food. This lasted for a few years until the woman fell ill and died and the man left for Booni, where he started a business that was able to flourish because his clientele were Tuareg who came to the south following unrest due to rebellion in the north.

Another family in Serma is called Kommangalluuij. By refusing a Riimaybe identity, this group denies having ever been slaves of the Fulbe. Kommangalluuji are different in that they voluntarily sought the protection of Maamudu Nduuldi when there was unrest in the area and offered their services to his army. The nobles see this as a form of slavery and consider these people as slaves. The Kommangalluuji, however, stick to their interpretation of the situation: being Kommangalluuji gives them pride in themselves and helps them to create an independent social identity.

The various families in this hamlet are related to a greater or lesser degree but not through family relations. What links them most closely is the fact that they no longer want to be seen as slaves and they each formulate, in their own way, a short history of themselves that attests to their free status. The story of this hamlet that emerged from the interviews we conducted over a ten-year period, however, shows that these people are firmly connected to the history of slavery in the area. That they reformulate this history in their own individual ways confirms this bonding link. The Rimaybe identity in this hamlet is still associated with slavery even though the inhabitants of Serma no longer work the land of their masters. But they have become linked through their sisters' marriages into the chief's family and can, therefore, claim the history of Maamudu Nduuldi as their own. As long as nobody talks openly about his or her family's role in Maamudu Nduuldi's army or about the real attachments they had, and still have, to various masters, this narrative about themselves as being free allows them an independent identity, albeit a fragile and undefined one, as the following story shows.

Dikko was married to one of Bilaali's brothers, who followed
Bilaali in his claim to be free. They tried to make their own living and considered the relationship they had with their master as one of friendship. The brother was much less successful than Bilaali in keeping his family going, and rumour had it that he and his wife were lazy. When he died, his wife was left with e1ght children. She could move only with difficulty, and her main income came from her work as a tattoo specialist for young (noble) Fulbe girls. We gave her some money as a gift because we were friends, with the intention being for her to use it to start a small business in the hamlet, as so many other Riimaybe women had done. Two years later, we came back and heard (from her) what really happened to the money. She bought nice presents and went to Dalla, where, as she openly admitted, her master lives. By that time, she was destitute and, with these gifts, she and all her children were able to stay with her former master, who fed them for at least six months. She returned to Serma with many more presents than she had left with. The sale of these presents gave her money to live off for another few months, but then she ran into financial problems again. Could we not give her some more money so that she could return to her master?

This hamlet reflects the history of the Sahel, where ecological and political insecurity have always dominated the landscape. Political hierarchies were always a way to devolve these risks to the lower strata of society (de Bruijn and van Dijk 2003). As Iliffe (1987) explains, one of the options for poor pastoralists who had lost their cattle was to become a slave, while living in the direct vicinity of a master. Moving to a small hamlet of former slaves has been another option. There, people are less confronted with their marginalization, but these pastoralists and their children became considered slaves all the same, and their children too. The crux of the matter is that marginal groups adopt other marginal groups to give them an identity and a place in society. The hamlet of Serma is a refuge for people who have become too poor to live elsewhere, and for those who want to escape slavery. The examples of Bella and some other families refer to such a refugee system, but this was not the origin of the hamlet. In fact, it originated because slaves wanted to live independent lives. Some succeeded and others did not. However, it is clear that, until now, they have lacked the political power to become rich farmers. 
Douentza: Confrontation with the modern world

"Ndimaaku ana welli" (nobility is fine) is a phrase uttered by a man from the former-slave group in Fulani society that lives in the small town of Douentza. The town is situated near a tarmac road and has shown steady economic growth and modernization over the past ten years. Modern life is part of this town; for example, the Coupe d'Áfrique de Nations 2002, which was held in Mali, could be followed on television, migrants invest their money there and introduce new ideas, and the democratization process is moving forward in the town. However, at the same time, the noble chiefs (who, in some cases, are today's mayors) still go around "their" (slave) villages after the harvest to collect their share of the Riimaybe harvest. In that same town, people are known as, and see themselves as, slaves and, even worse, they are still called "slave" (Maccudo) and are not regarded as part of Ndimaaku.

The case that opened this article shows that there is, indeed, resistance to the oppression: it is no longer accepted by all Riimaybe that their masters force them to vote for them. Today, most of the Rimaybe of the noble Fulbe and of Diawaambe in Douentza still live together in the fifth quarter. The majority work their masters' land and still give their masters part of the harvest. Other Riimaybe live dispersed in town: some are linked to Fulbe originating from Douentza town, while others are connected with Fulbe in different villages and hamlets. In some cases, these Riimaybe have come to Douentza literally to flee the relations of subordination in villages and to live in town in relative autonomy. Still others have arrived in town to try their luck, while others came as refugees after the droughts of the 1970s and 1980s. Most Riimaybe are cultivators and may be involved in the livestock trade, in the weaving of cotton or in construction work. Very few Diimaajo are big traders (Zondag 2004), nor do they play an important role in politics or in Islamic power structures. This does not mean that the Riimaybe in town are poor, on the contrary. As their masters freely admit, many Riimaybe in town today are richer than their former masters because of the variety of activities they can engage in.

How constraining slave descent can still be in this urban environment is evident from Bura's story. Bura heard of his slave descent only after he became an adult, when his mother's master (who was, therefore, his master too), a Diawaando from Dalla, divulged this information. His mother had never worked for her master but lived in a separate village and had her own commercial activities and fields. She worked hard to feed her children, husband, and other relations. Bura's father died when he was young, and he lived only three years with his mother, before going to stay with his father's family, who were also Riimaybe. His father's father left the area where he was a slave to set himself up as a free man in town. He went by the name Cissé, a name of Islamic scholars, which could indicate that his master may have had a religious background. Bura told me that his father was a friend of the chief of Douentza and that is how they came to live in the fifth quarter and be Douentza citizens. In this family, he was encouraged to go to school, which he did until the fifth class, when he left to work in the fields and to become a weaver. Initially, he stated that being a Diimaajo did not influence his life, but when we discussed the matter further, he realized that indeed, even today, he visits his mother's master and brings him presents. He also has close ties to the Rimaybe in town.

He realizes that only outside Douentza, in the south, can he engage in work as a trader or even as a weaver. He accepts that all the work he does is related to the history of slavery in the area. When Bura worked as an assistant for us, he was especially effective because he is a dêscendant of a former slave, and the status of former slave made him a trustworthy person with an intermediate position in the Fulbe pastoral society of nobles where we were conducting research. He was considered our "slave" and was, therefore, accepted by the others. He almost automatically took up tasks that are reserved for slaves, such as butchering the various goats that were killed for us during the many trips we made. He was also called Maccudo, although often in a friendly way. He realized that he did, indeed, still behave as he was expected to because of his position as a member of the former-slave group. Although he considered himself emancipated, and from a family where slavery was something of the past, he had also come to the conclusion that this might not be true. Then, he started to consider his children's futures. Would they escape their position if they stayed in Douentza? He was not sure and felt momentarily disoriented.

From talking to Yaaya, a man of about fifty-five years old, 
another aspect of being a slave today came to the fore. He analyzed his own situation quite clearly: being attached to his master's family is an obligation. There is no other choice. Exceptionally, he chose to remain dependent on his father's master, not his mother's. The history of slavery experienced by his parents and grandparents is well-known to him, but he does not know how to rid himself of the situation of bondage in which he finds himself. He works his master's land and lives in his father's house, which virtually belongs to this master. He does not like to be called a Maccudo, or even Diimaajo, because, as he admits himself, he is a Diimaajo who did not diimaay, that is, who did not free himself. He was never freed, and his master refuses to free him. Although he could claim the rights of a freeman through the modern administration, he does not see any point in doing so. Old norms and rules will not be changed if he does and, in practice, he will always bear the social stigma of being a former slave. Officially, he may marry a noble woman, but would any noble family really allow him to do so?

Yes indeed I am free in the eyes of modern law but that does not help me. The land I work belongs to the master of my father who has become my master, and if he takes back the land this will be a disaster for me. As long as I do not disturb our relationship, he will not withdraw the land, but leave me to live my life. I really hope that my children will marry a Diimaajo, and I hope they will have respect for the master. Do we have another choice?

\section{Conclusion}

Do the Riimaybe have a past of their own? This article shows that a personal historical narrative is largely absent and that most former slaves rely on the history of their masters. The only reference to their own history is a vague indication of where their parents came from and what their ethnic background may have been before they were captured. Reflections on the past differ in different groups. One of these groups are the Riimaybe who still live next to their masters. These masters still dominate the politics of the region, and they are in power in modern-day Mali because of their monopoly on claims according to historical right. They own history by means of a tarikh and strong claims to the land. Their slaves may be better off following the history of their master and fulfilling the roles expected of them in order not to lose the rights linked to their position as slaves. In this case, being a slave is probably the best option as it can be considered a kind of social security.

Another group are the Rimaybe who have literally detached themselves from their masters but have not left the region. Their relationships with their masters still exist and they - as well as their masters - may, from time to time, "use" the relationship, for example, in times of need. They do not construct a historical counter-narrative, but, by reflecting on the past, they define their own position more clearly. Their parents took the decision to free themselves. They are grouped together with (former) noble people who also fled and say that they have never been enslaved. In their discourse, there is a certain resistance to the social system, but they cannot (yet) escape. Finally, there is the group in town, some of whom are linked to the old chiefdom of Douentza. Others who came from outside have joined this group, but these people have no common history. They have not created a history, nor do they consciously reflect on their past. Their problem is direct confrontation with the modern or outside world: the feeling of being dependent is often unbearable. They try to live their lives in the present.

The three groups reflect on who the Riimaybe are, but this is done while facing certain dilemmas. Social dilemmas include who to be and how to (re-)formulate history according to the position they can adopt in present-day society. Material dilemmas surround access to development agencies, education, and policy. These reflections inform the construction of a narrative that allows the various Riimaybe to construct their own social identity. This is an ongoing process in which social relations are negotiated. Social hierarchies and their content are perhaps not changing in form but are altering in content. Developments in society are reflected in the way the different groups define and redefine their social identity. At present, a dominant change is the process of democratization in which technological changes, such as the introduction of television, make people more aware of the outside world.

The position of the Riimaybe vis-à-vis their so-called former masters, as well as the construction of their own identity, is a field of negotiation in which social and power relations in society are being redefined. In this process, reference is made to a certain past, a past that is open to various interpretations and configurations. In 
this negotiation between Riimaybe and the nobles in the Hayre, it would appear that the nobles are still in the stronger position. They are keeping their role as political leaders, and theirs is the only historical narrative (Angenent, Breedveld, de Bruijn et van Dijk 2002). The Riimaybe are not unified enough to have only one narration of their history and, therefore, cannot speak with only one voice. They have not yet removed the rope from around their necks!

\section{Notes}

1 Anti-slavery organizations include, for example, Timidria in Niger (Tidjani Alou 2000), Ganda Koi in Mali for Bella (Tuareg slaves), www.sosesclaves.com in Mauritania (Ruf 1999; see Smit on www.xs4all.nl/ $\sim$ pietersm). We realize that the topic may be sensitive also for the people who told us their stories, for which we are very grateful. Those stories that were not meant for the greater public are not used in this article. Where we deemed necessary, we changed names of people, but it is difficult and not necessary to hide the places where they live.

${ }^{2}$ Lotte Pelckmans worked in the Douentza region in 2001; Miriam de Bruijn worked there for several longer periods from 1987 to 2002 . The authors thank Han van Dijk, who worked together with Mirjam, for his valuable comments on earlier drafts of this article.

${ }^{3}$ De Bruijn and van Dijk $(1995,2001)$ have made a reconstruction of the area's past with the help of archival material and oral traditions found in the area. The oral traditions are published in Angenent, Breedveld, de Bruijn et van Dijk (2002). Although the authors think this history relies on facts, it is clearly a history based on the noble version of the sequence of events.

${ }^{4}$ Often, this complex of rules is labelled pulaaku, but, as we have argued elsewhere, the literal translation of pulaaku is "Fulbe community," and each Fulbe community has its own sets of rules. These sets of rules also resemble the moral codes of the Tuareg, of the Sonrai, and of many other Sahelian groups (Breedveld et De Bruijn 1996).

${ }^{5}$ We make use of the English translation of these French terms (condition and estate) following Ruf (1999).

${ }^{6}$ In this case study, we will focus on relations between the Riimaybe and the Weheebe because research was conducted focusing mostly on these two groups, leaving out the Moodibaabe, the Jawaambe, and the Nyeeybe (griots). The bond between the Riimaybe and the Weheebe has always been the strongest.

${ }^{7}$ Diawara $(1989,76)$ wrote about the Jaara kingdom and the central role of Soninke women slave songs in guarding the history and genealogies of the enslaved. This might explain why Maman knew how to sing.

${ }^{8}$ During Pelckmans's visit to Dalla, Maman's grandsons were about to get married, and Maman decided she would sing once more on this occasion, but her family did not allow her to do so.

${ }^{9}$ A family member of Maman's even confided that Maman once bought a cow for her former master and that she freed herself officially in that way.

${ }^{10}$ This case of Serma and the following case of Douentza were gathered by Mirjam de Bruijn.

\section{Bibliography}

Angenent, C., A. Breedveld, M. de Bruijn et H. van Dijk. 2002. Les rois des tambours au Haayre, récitée par Aamadu Baa Digi, griot des Fulbe à Dalla (Mali). Leiden: Brill.

Botte, R. 1994. "Stigmates sociaux et discriminations religieuses: 1'ancienne classe servile au Fuuta Jaloo." Cahiers d'études africaines 34, nos.1-3: 109-36

- 2003. "Le droit contre l'esclavage au Niger." Politique africaine no. 90, 127-43.

Breedveld, A. 1995. "Form and Meaning in Fulfulde: A Morphological Study of Maasinankoore." PhD thesis, Leiden University.

Breedveld, A. et M. de Bruijn 1996. "L'image des Fulbe: Analyse critique de la construction du concept de Pulaaku." Cahiers d'études africaines 144 (36-4): 791-821.

de Bruijn, M. and H. van Dijk. 1994. "Drought and Coping Strategies in Fulbe Society in the Hayre (Central Mali): A Historical Perspective." Cahiers d'études africaines 34 (1-3): 85-108.

- 1995. Arid Ways, Cultural Understandings of Insecurity in Fulbe Society, Central Mali. Amsterdam: Thela Publishers.

- 2001. "Ecology and Power in the Periphery of Maasina: The Case of the Hayre in the Nineteenth Century." The Journal of African History 42, no.2: 217-38.

- 2003. "Risk Positions and Local Politics in a Sahelian Society: The Fulbe of the Hayre in Central Mali." In (Inter)National Political Economies and Local Ecologies: Rural African Livelihoods in a Political Ecology Context, edited by Bill Mosely and B. Ikubolajeh Logan. London: Ashgate.

Diawara, M. 1989. "Femmes, servitude et histoire: les traditions orales historiques des femmes de condition servile dans le royaume de Jaara (Mali) du XVE au milieu du XIXE siècle." History in Africa 16: 71-96.

Evers, S. 2002. Constructing History, Culture and Inequality: The Betsileo in the Extreme Southern Highlands of Madagascar. Leiden: Brill. 
Finley, M.I. 1981. Esclavage antique et idéologie moderne. Paris: Edition de minuit.

Griep, S. 2004. "Coping strategies of the Riimaybe in Douentza, Central Mali." In Sahelian Pathways, Climate and Society in Central and South Mali, edited by M. de Bruijn, H. van Dijk, M. Kaag and K. van Til. Leiden: Brill.

Hardung, C. 1997. "Ni vraiment Peul, ni vraiment Baatombu: le conflit identitaire des Gando." In Trajectoires peules au Bénin, sous la direction de T. Bierschenk et P. Le Meur. Paris: Karthala.

-1998. "Exclusion sociale et distance voulue: des rapports entre les Gannunkeebe et les Fulbe." In Regards sur le Borgou: pouvoir et altérité dans une région ouest-africaine, sous la direction de $\mathrm{E}$. Boesen, C. Hardung, et R. Kuba. Paris: L'Harmattan.

Iliffe, J. 1987. The African Poor: A History. Cambridge: Cambridge University Press.

Jansen, J. and C. Zobel. 2002. "The Guest Is a Hot Meal: Questioning Researchers' Identities in Mande Studies." In Africanizing Knowledge: African Studies Across the Disciplines, edited by T. Falola and C. Jennings. Brunswick, New Jersey and London: Transaction Publishers.

Klein, M. 1989. "Studying the History of Those Who Would Rather Forget: Oral History and the Experience of Slavery." History in Africa 36: 209-17.

- 1999. "Slavery and French Rule in the Sahara." In Slavery and Colonial Rule in Africa, edited by M. Klein and S. Miers. London: Frank Cass.

Klein, M. and S. Miers. 1999. "Introduction." In Slavery and Colonial Rule in Africa, edited by M. Klein and S. Miers. London: Frank Cass.

Kopytoff, I. and S. Miers, eds. 1977. Slavery in Africa: Historical and Anthropological Perspectives. Madison: University of Wisconsin Press.

Lambek, M. 1996. "The Past Imperfect: Remembering as Moral Practice." In Tense Past: Cultural Essays in Trauma and Memory, edited by $P$. Antze and M. Lambek. London: Routledge.

Lovejoy, P., ed. 1981. The Ideology of Slavery in Africa. London: Sage.

Meillassoux, C. 1982. "The Role of Slavery in the Economic and Social History of Sahelo-Sudanic Africa." In Forced Migration: The Impact of the Export Slave Trade on African Societies, edited by J.E. Inikori. London: Hutchinson and Co.

_. 1986. Anthropology de l'esclavage, le ventre de fer et d'argent. Paris: Presses.
McDougall, E.A. 1988. "A Topsy-Turvy World: Slaves and Freed Slaves in the Mauritanian Adrar 1910-1950." In The End of Slavery in Africa, edited by S. Miers and R. Roberts. Madison: University of Wisconsin Press.

N'Gaide, A. 1999. "Conquête de la liberté, mutations politiques, sociales et religieuses en haute Casamance: les anciens maccube du Fuladu \{région de Kolda, Sénégal)." In Figures peules, sous la direction de R. Botte, J. Boutrais et J. Schmitz.

Pelckmans, L. 2003. "Il y a toujours la corde: Bondedness of Former Courtslaves in Dalla." PhD thesis, University of Leiden.

Riesman, P. [1974] 1977. Freedom in Fulani Social Life: An Introspective Ethnography. Chicago / London: The University of Chicago Press.

-1992. First Find Your Child a Good Mother: The Construction of Self in Two African Communities. New Brunswick, New Jersey: Rutgers University Press.

Ruf, U.P. 1999. Ending Slavery: Hierarchy, Dependency and Gender in Central Mauritania. New Brunswick, New Jersey and London: Transaction Publishers.

Shaw, R. 2002. Memories of the Slave Trade: Ritual and Historical Imagination in Sierra Leone. Chicago / London: The University of Chicago Press.

Stilwell, S. 1999. "Amana' and 'Asiri': Royal Slave Culture and the Colonial Regime in Kano, 1903-1926." In Slavery and Colonial Rule in Africa, edited by M. Klein and S. Miers. London: Frank Cass.

Tidjani Alou, M. 2000. "Đémocratie, exclusion sociale et quête de la citoyenneté: cas de 1" association Timidriá au Niger." Journal des Africanistes 70, nos. 1-2: 173-96.

Trouillot, M.R. 1995. Silencing the Past: Power and the Production of History. Boston: Beacon Press.

Vereecke, C. 1994. "The Slave Experience in Adamawa: Past and Present Perspectives from Yola (Nigeria)." Cahiers d'études africaines 34, nos.1-3: 23-53.

Wolf, E. 1981. Europe and the People without History. Berkeley, California: University of California Press.

Zondag, R. 2004. "Dynamics of a Rural Centre: Douentza in Central Mali." In Sahelian Pathways, Climate and Society in Central and South Mali, edited by M. de Bruijn, H. van Dijk, M. Kaag and K. van Til. Leiden: Brill. 